\title{
Academic degrees. Standardization in English language
}

\author{
Titulos universitários. Normalização no idioma Inglês
}

\author{
Saul Goldenberg ${ }^{1}$, Jacques Matone ${ }^{2}$ \\ 1. Editor-in-Chief. \\ 2. English language consultant.
}

Acta Cirúrgica Brasileira has an increasingly tendency to publish scientific manuscripts in the English language. Nevertheless, those articles submitted for publication reveal significant heterogeneity concerning authors' academic degrees. As articles are sent from all over the Country, regional jargons are frequently used. Even though our unique official language, these variations may lead to misunderstandings. The lack of standard denominations for the academic degrees reminds us of the Tower of Babel. A uniform way of writing shall improve understanding and may diminish regional distances to a common language.

Some scientific journals do not require authors academic degree expressed in the text, and in some cases it is enough to cite the institution where the study was performed. According to "Vancouver style" [ICMJE Out 2004], regarding EDITORIAL LIBERTY AND INTEGRITY, “.... at the same time, every journal has editorial requirements uniquely suited to its purposes. Editors-in-chief must have full authority for determining the editorial content of the journal generally referred to as "editorial independence". Uniforms requirements (Vancouver) are instructions to authors to prepare originals, but not to Editors concerning publication style..."

Acta Cirúrgica Brasileira requires the specification of the higher academic degree of each author, in order to let manuscripts to be published. However, when translated into English, a wide range of distortions and lack of respect to the scientific language are observed. Due to this fact, a standardization of these academic degrees in English turns out to be necessary, so as to instruct authors in their manuscripts.

We collected some examples extracted from manuscripts sent for publication in Acta Cirúrgica Brasileira, from different authors, in the left column. In the middle column, the recommended form and in the right column the Portuguese version.

We expect that these uniform requirements will be observed by all authors. As a matter of fact, some denominations not on the list may arise. Our aim will be to determine, together with the Editorial board, the most suitable way to keep our journal away from Tower of Babel and help our readers to find precise and uniform information in each article published.

ACADEMIC DEGREES EXAMPLES

\begin{tabular}{|c|c|c|}
\hline In portuguese & Found in Acta Cir Bras & Recommended \\
\hline Acadêmico & Scientific Initiation Students & Graduate Student \\
\hline Chefe de Disciplina & Chief of Discipline & Head of Division \\
\hline Chefe de Serviço & Chief of the Group & Surgeon-in-Chief \\
\hline $\begin{array}{l}\text { Departamento } \\
\text { Disciplina } \\
\text { Setor }\end{array}$ & $\begin{array}{l}\text { Department } \\
\text { Discipline } \\
\text { Sector }\end{array}$ & $\begin{array}{l}\text { Department } \\
\text { Division } \\
\text { Unit }\end{array}$ \\
\hline Doutor & Doctor in Basic Sciences & $\mathrm{PhD}$ \\
\hline Doutor & Doctor (Phd) In Sciences & PhD \\
\hline Doutor & Post-Graduated. Doctorate Degree. & $\mathrm{PhD}$ \\
\hline $\begin{array}{l}\text { Doutor, } \\
\text { Chefe de Disciplina }\end{array}$ & PhD, Chief of Discipline & PhD, Head \\
\hline Médico & Attending Physician & MD \\
\hline Médico, Doutor & MD, PhD of Medicine & $\mathrm{MD}, \mathrm{PhD}$ \\
\hline Médico Residente & Resident & MD. Resident \\
\hline Mestre & Master In Basic Sciences & Master \\
\hline $\begin{array}{l}\text { Pós-Graduando } \\
\text { nível de Doutorado }\end{array}$ & $\begin{array}{l}\text { Doctoral Fellow } \\
\text { Post-Graduate Student }\end{array}$ & Fellow PhD degree \\
\hline $\begin{array}{l}\text { Pós-Graduando } \\
\text { nível de Mestrado }\end{array}$ & $\begin{array}{l}\text { Master Fellow } \\
\text { Post-Graduate Student }\end{array}$ & Fellow Master degree \\
\hline Pós-Graduando & MD. Postgraduate Course Of Surgery, & MD. Fellow of Surgery \\
\hline Professor & Professor of Surgery & Full Professor \\
\hline $\begin{array}{l}\text { Prof. Adjunto } \\
\text { Prof. Associado }\end{array}$ & Adjunct Professor & Associate Professor \\
\hline Prof. Afiliado & Affiliated Professor of Surgery & Affiliate Professor \\
\hline Prof. Adjunto & Associated Professor & Associate Professor \\
\hline Prof. Assistente & Professor Assistant & Assistant Professor \\
\hline $\begin{array}{l}\text { Prof. Assistente } \\
\text { Chefe de Disciplina }\end{array}$ & $\begin{array}{l}\text { Assistant Professor Doctor and } \\
\text { Head of the Discipline }\end{array}$ & $\begin{array}{l}\text { Assistant Professor, } \\
\text { Head of Division }\end{array}$ \\
\hline Prof. Colaborador & Colaborator professor & Volunteer Faculty \\
\hline Prof.Titular & Titular Professor & $\begin{array}{l}\text { Chairman } \\
\text { Full Professor }\end{array}$ \\
\hline Prof. Visitante & Visitor & Visiting Professor \\
\hline Prof. Titular e Chefe & Titular Professor and Head & Chairman and Head \\
\hline $\begin{array}{l}\text { Titular e } \\
\text { Chefe de Disciplina }\end{array}$ & Chairwoman And Head & Chairwoman, Head \\
\hline
\end{tabular}

\section{Acknowledgements}

To Robert Zhong, Department of Surgery, University of Hospital London, Ontario, Canada and Fernando Mardiros Herbella, Department of Surgery, University of California, San Francisco, USA. 